\title{
Properties of the Gamma Haemolysin of Staphylococcus aureus 'Smith 5R'
}

\author{
By H. B. FACKRELL* AND G. M. WISEMAN \\ Department of Medical Microbiology, University of Manitoba, Winnipeg, Canada
}

(Received 25 January 1974; revised 30 June 1975)

\section{SUMMARY}

Purified gamma haemolysin of Staphylococcus aureus was characterized in relation to the alpha, beta and delta haemolysins. The sedimentation coefficient of the gamma lysin was 2.65 , somewhat higher than the $s_{20,}$, values of $I \cdot 4$ for freshly purified alpha lysin and $\mathrm{I} \cdot 8$ for the beta lysin. The molecular weight of gamma lysin determined by gel filtration was 45000 daltons. The pI of gamma lysin was $6 \cdot 0$, while that of the alpha, beta and delta lysins ranged from 8.5 to $9 \cdot 6$.

The amino acid analysis of gamma lysin was characterized by low levels of methionine and histidine. Methionine was, however, the $N$-terminus, which suggested that all of the amino acid might be involved in the $N$-terminal group.

The gamma lysin was immunologically distinct from the alpha, beta and delta lysins by quantitative precipitin tests; in Ouchterlony agar gel diffusion tests, single lines of precipitation were observed which showed no evidence of cross-reactions amongst the four haemolysins.

Gamma, beta and delta lysins had no effect in mice when injected at increasing doses ranging from 0 to $100 \mu \mathrm{g}$. The alpha lysin killed mice, the $\mathrm{LD}_{50}$ dose being $0.68 \pm 0.12 \mu \mathrm{g}$, or 27 to $34 \mu \mathrm{g} / \mathrm{kg}$ mouse tissue. Gamma lysin was, however, lethal for guinea pigs when $50 \mu \mathrm{g}$ quantities were injected intracardially. Gamma lysin also lysed human leucocytes and destroyed C-6 (human lymphoblast) cells.

Some nitrogen and phosphorus was released from human erythrocyte membranes treated with gamma lysin, when compared to untreated cells, and the rate of this release was linear over a $3 \mathrm{~h}$ period. Gamma lysin had no detectable effect on phospholipids extracted from erythrocytes or on lipid-free membrane protein. However, the haemolytic reaction was inhibited by erythrocyte membranes when these were added to lysin-red cell suspensions. Furthermore, human red cell phospholipids competitively inhibited haemolysis. Haemolysis was also inhibited by EDTA and activity could be restored by dialysis. The haemolytic reaction required sodium ions.

\section{INTRODUCTION}

The gamma haemolysin of Staphylococcus aureus, first discovered by Smith \& Price (1938) has usually been confused with delta lysin (Elek, 1959) and consequently it has been poorly characterized until quite recently (Guyonnet \& Plommet, 1970; Mollby \& Wadstrom, I97I).

We have compared the chemical and biological properties of purified gamma lysin with those of purified alpha, beta and delta lysins.

\section{METHODS}

Production and purification of gamma lysin. These procedures with the 'Smith $5 R$ ' strain of Staphylococcus aureus are described in the preceeding paper (Fackrell \& Wiseman, 1976). Alpha lysin was purified by the method of Wiseman, Caird \& Fackrell (1974), and beta lysin by a modification of the method of Wiseman \& Caird (1967) in which a column of Sephadex

- Present address: Department of Biology, University of Windsor, Windsor, Ontario, Canada. 
G-75 was equilibrated with the buffer of Hallander (1963). Haemolysin, measured in haemolytic units (h.u.), in the column effluent was pooled, concentrated and lyophilized. Delta lysin was purified as before (Caird \& Wiseman, 1970).

Haemolysin titrations. These were performed as described by Wiseman \& Caird (1972). Sheep blood was used in the titration of beta lysin, human blood with delta and gamma lysins, and rabbit blood with alpha lysin. All lysin titrations were supplemented with I mM- $\mathrm{Mg}^{2+}$ as described by Wiseman \& Caird (1967). The activity of beta haemolysin is enhanced in the presence of $\mathrm{Mg}^{2+}$ ions, but they have no effect on alpha, gamma and delta lysins. Blood from other animal species was obtained from animals kept in this Department or from the National Biological Laboratories, Winnipeg, Canada. Human erythrocytes $\left(\mathrm{Rh}^{+}\right.$, group $\left.\mathrm{O}\right)$ were supplied by the Canadian Red Cross in Winnipeg.

Kinetics of haemolyis. Kinetic experiments were performed in an automated SP $800 \mathrm{~B}$, double beam recording spectrophotometer (Pye-Unicam, Cambridge), the cuvette holder of which was equipped with a constant temperature water jacket set at $37^{\circ} \mathrm{C}$. Washed red cells were suspended in buffered saline $(0.0 \mathrm{I} \mathrm{M}, \mathrm{pH} \mathrm{7.0})$ in a cuvette of $\mathrm{I} \mathrm{cm}$ light path so that a I : 2 dilution of the cells would have an $E_{650}$ of 1.8 . An equal volume of gamma lysin at the appropriate concentration was added to the cells, after which the extinction was monitored continuously or at specified time intervals as required. The slope of the line which depicted a decrease in extinction versus time, expressed as extinction change/min, reflected the concentration of haemolysin present. The effect of membrane phospholipid fractions, lipid-free membrane protein or red cell cytoplasm on the haemolysis of red cells by the gamma lysin was measured in the same way. The phospholipids or membrane proteins were added to the red cell suspension just before the addition of lysin and extinction changes were monitored. Controls were present and automatically compensated for by the double beam spectrophotometer.

Membranes. Human erythrocyte membranes were prepared by the method of Dodge Mitchell \& Hanahan (1963). The method of Rose \& Oklander (1965) was used in the extraction of phospholipids from erythrocytes. Lipid-free membrane protein was prepared from red cells (Rosenberg \& Guidotti, 1968).

Effect of EDTA haemolysis of red cells by gamma lysin. Equal volumes of EDTA dissolved in phosphate buffered saline at $\mathrm{pH} 7 \cdot 0$ were added to dilutions of haemolysin such that the combined volume was $\mathrm{I} \mathrm{ml}$. One $\mathrm{ml}$ of erythrocytes was added to each tube. Incubation and determination of the haemolytic end point were performed as described by Wiseman \& Caird (1972). In some titrations, solutions of cations were added to the gamma lysin dilutions in place of or with the EDTA, before addition of the erythrocytes. In one experiment, sodium or potassium ions were added to the lysin dilution, and after the addition of red cells the rate of lysis was followed in the spectrophotometer as described for kinetic experiments.

Antibodies. Antibodies to the haemolysins were prepared in rabbits as described by Fackrell \& Wiseman (1974). Immunodiffusion, immunoelectrophoresis and quantitative precipitin tests were performed and antibodies purified by the methods of Campbell et al. (1970).

Tissue culture. Cells of the C-6 line (Ida, Sairenji \& Hinuma, 1972) were obtained from Dr A. Wallbank of this Department. They were grown in stationary cultures at $37^{\circ} \mathrm{C}$ in McCoy's 5A medium (Grand Island Biological Corp., New York, N.Y., U.S.A.) supplemented with $10 \%(\mathrm{v} / \mathrm{v})$ foetal calf serum and harvested at a concentration of $10^{7}$ cells $/ \mathrm{ml}$. The cells were washed with the McCoy medium which contained $2.5 \%(\mathrm{v} / \mathrm{v})$ calf serum and resuspended to the original volume in this medium.

Phospholipids. Thin-layer chromatrography was performed as described by Fackrell (1974) for detection of phospholipids, which were identified by ascending chromatography 
on glass plates coated with silica gel G (Merck). Development was effected in Marinetti's (1962) 'solvent and the phospholipid spots were visualized with rhodamine 6G or ammonium molybdate sprays (Ansell \& Hawthorne, 1964).

$N$-terminal amino acids. The technique of Fraenkel-Conrat, Harris \& Levy (1955) was used with the following modification. Dinitrophenyl amino acids were chromatographed on glass plates coated with silica gel G (Merck) prepared as described by Stahl (I965). Watersoluble and ether-soluble extracts were subjected to ascending chromatography in the following solvent systems recommended by Pataki (1968) (parts by vol. in brackets): $n$-propanol-ammonium hydroxide (7:3); chloroform-benzyl alcohol-acetic acid (70:30:3); chloroform-methanol-acetic acid (95:5:1); benzene-pyridine-acetic acid (80:20:2); and chloroform-t-amyl alcohol-acetic acid (70:30:3).

Quantitative assays. Acid-soluble phosphorus was determined by the method of Fiske and Subbarow as described by Leloir \& Cardini (1955). Total phosphorus determination was also based on a method described by the latter authors.

Total carbohydrate was estimated by the anthrone method (Kabat \& Mayer, 196I). Methods cited by these authors were also applied to the determination of pentose, deoxypentose, reducing sugar, hexosamine and sialic acid. Nitrogen was estimated by the microKjeldahl technique given by Markham (1942), while protein was assayed by Bailey's (1967) modification of the Lowry protein reaction. Amino acid analysis was done by Dr F. Labella and Dr F. Stevens of this university. Corrections were made for the partial destruction of acid-labile amino acids.

Other techniques. Polyacrylamide disc gel electrophoresis, electrofocusing and sedimentation velocity analysis were as described by Wiseman et al. (1974). Molecular weights from Sephadex chromatography were determined by the method of Andrews (1964).

Chemicals. Pronase was obtained from Calbiochem, purified phospholipids were purchased from General Biochemicals, Chagrin Falls, Ohio, U.S.A., and phospholipase C (Clostridium perfringens alpha toxin) was obtained from Worthington Corp., Freehold, New Jersey, U.S.A.

\section{RESULTS}

\section{Physico-chemical characteristics of gamma lysin}

Disc gel electrophoresis of purified gamma lysin together with purified samples of alpha, beta and delta lysins showed that the gamma lysin cannot be distinguished by this method from the alpha lysin (Fig. I); both of these lysins migrate toward the cathode. Beta lysin is displaced to the right of the alpha and gamma lysins, while delta lysin moves very little toward the cathode under the conditions of the experiment.

A single peak $\left(s_{20, \pi}=2 \cdot 6\right)$ for gamma lysin was obtained in the ultracentrifuge. Sedimentation coefficients of alpha and beta lysins were $\mathrm{I} \cdot 4$ and $\mathrm{I} \cdot 8 \mathrm{~S}$ respectively. If the alpha lysin was allowed to stand for several days at $4{ }^{\circ} \mathrm{C}$, the $s_{20 \text {,w }}$ became 3.0 as reported elsewhere (Wiseman et al., 1974).

One per cent extinction coefficients were calculated for the gamma lysin from the slope of the extinction plot at $280 \mathrm{~nm}$ versus concentration. The $E_{280}^{\mathrm{icm}}$ for gamma lysin was calculated to be 28.35 compared with 29.08 for delta. The $E_{280}^{\mathrm{Icm}}$ for alpha lysin was 13.56 while that for beta lysin was $4 \cdot 24$.

Isoelectric focusing of the four haemolysins is shown in Fig. 2. The pI values of beta and delta lysins are 9.5 and 9.6 respectively. The $\mathrm{pI}$ of alpha lysin is 8.5 while that for gamma lysin is $6 \cdot 0$. Only single peaks of protein were observed to correspond with the haemolytic activity of the purified preparations in each case. 

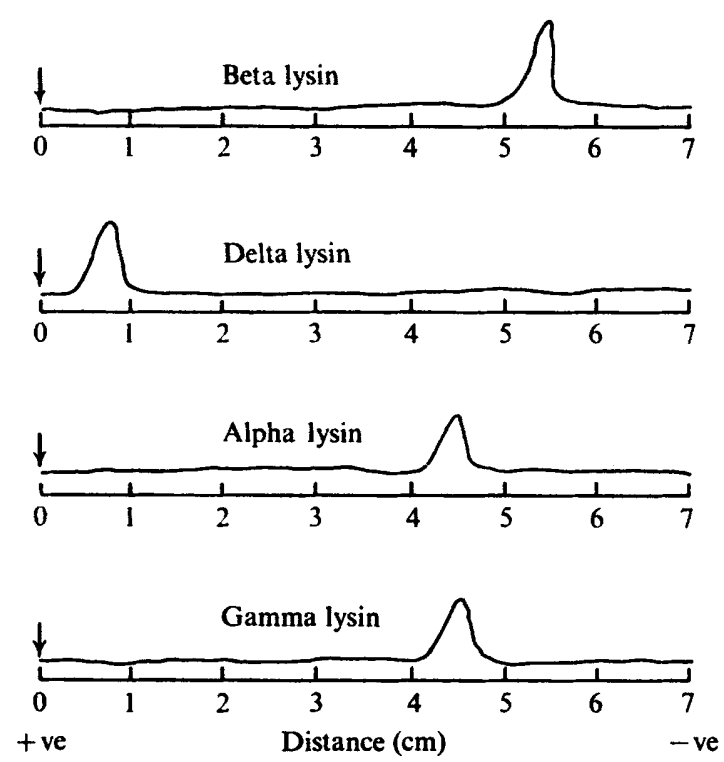

Fig. I. Densitometer scan of purified haemolysins subjected to polyacrylamide disc gel electrophoresis. The direction of migration is from left to right.
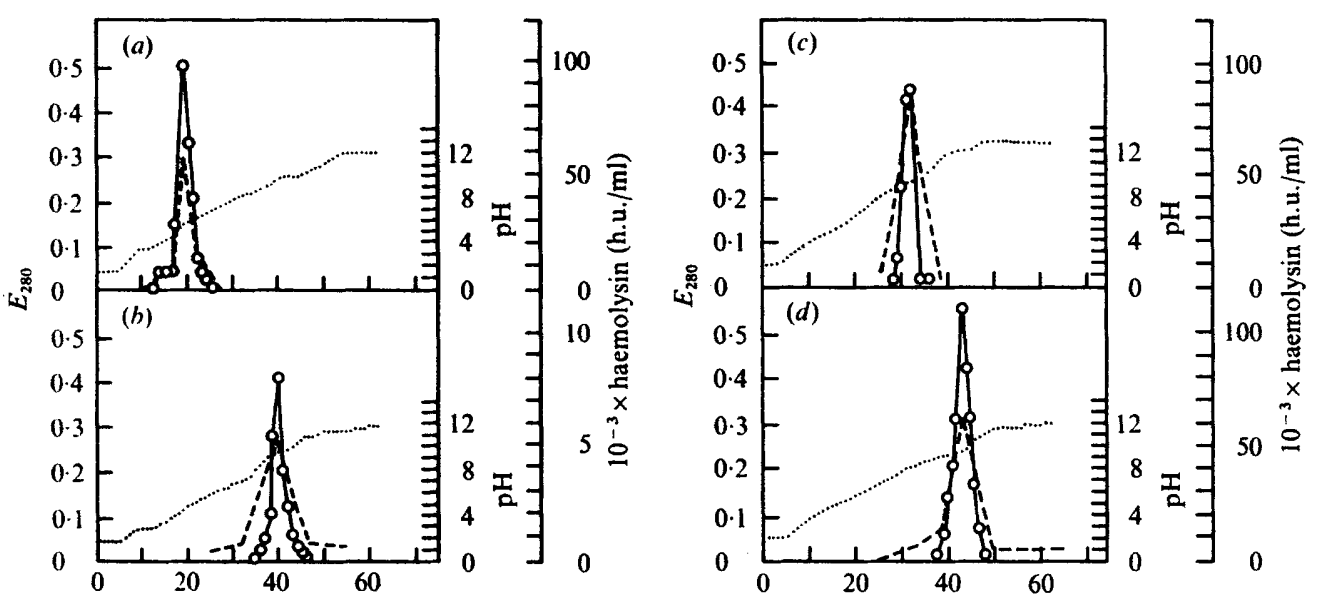

Fraction no. $(2 \mathrm{ml} /$ tube $)$

Fig. 2. Electrofocusing of purified haemolysins. _- Haemolytic activity; - - - -, extinction; ...... pH gradient. (a) Gamma lysin (pI 6.0); (b) delta lysin (pI 9.6); (c) alpha lysin (pI 8.5); (d) beta lysin (pI 9.5).

The molecular weight of the gamma lysin based on gel filtration was 45000 daltons, as was that of the alpha lysin (Fig. 3). The molecular weights of the beta and delta lysins by gel filtration were quite different; that for beta lysin was 26000 daltons, half the value for alpha and gamma lysins, while the molecular weight of delta lysin was beyond the resolution of the Sephadex column, probably of the order of 200000 or greater.

An amino acid analysis of the gamma lysin is shown in Table $I$. The data are characterized by a large number of aspartic and glutamic acid residues as well as a high glycine content. In this respect the gamma lysin is not different from the alpha, beta or delta lysins shown in the Table for comparison. Cysteine and methionine are either absent or present in small amounts 


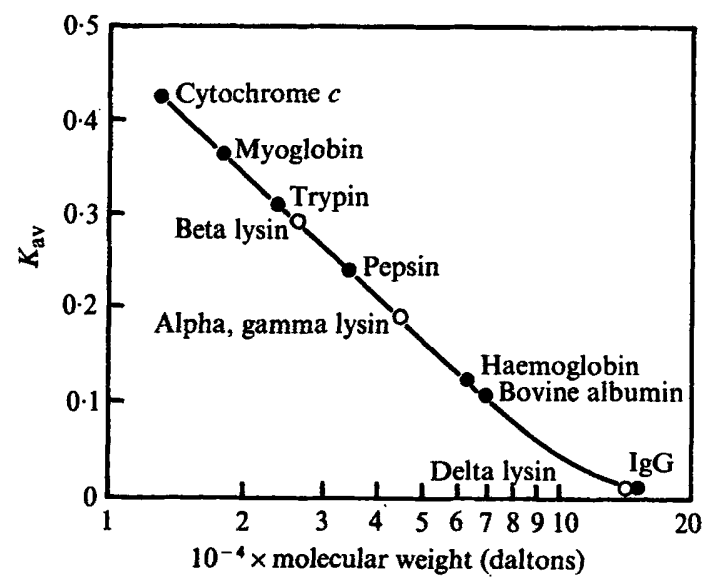

Fig. 3. Molecular weight determination of purified haemolysins on a column of Sephadex G-75. $K_{\mathrm{av}}$, the partition coefficient; IgG, immunoglobulin G.

Table 1. Amino acid composition of staphylococcal haemolysins

\begin{tabular}{|c|c|c|c|c|}
\hline \multirow[b]{2}{*}{ Amino acid } & \multicolumn{4}{|c|}{ Composition (residues/1000 amino acid residues) } \\
\hline & Alpha & Beta & Gamma & Delta \\
\hline Aspartic acid & $121 \cdot 2$ & $135 \cdot 1$ & $142 \cdot 0$ & $164 \cdot x$ \\
\hline Threonine & $56 \cdot 9$ & $53 \cdot 8$ & $68 \cdot 0$ & 119.9 \\
\hline Serine & $65 \cdot 1$ & $98 \cdot 7$ & $77 \cdot 4$ & $96 \cdot 3$ \\
\hline Glutamic acid & $93 \cdot 0$ & $116 \cdot 9$ & $102 \cdot 4$ & $66 \cdot 4$ \\
\hline Proline & $8 \mathrm{I} \cdot 2$ & - & $50 \cdot 2$ & 14.0 \\
\hline Glycine & $170 \cdot 1$ & $121 \cdot 2$ & $125 \cdot 0$ & 112.4 \\
\hline Alanine & $75 \cdot 8$ & $78 \cdot 2$ & $63 \cdot 2$ & $75 \cdot 2$ \\
\hline Valine & $50 \cdot 1$ & $57 \cdot 8$ & $51 \cdot 0$ & $76 \cdot 0$ \\
\hline Cysteine & - & $12 \cdot 2$ & - & - \\
\hline Methionine & $12 \cdot 1$ & - & $3 \cdot 5$ & - \\
\hline Isoleucine & $40 \cdot 4$ & $52 \cdot 5$ & $44 \cdot 4$ & $102 \cdot 7$ \\
\hline Leucine & $46 \cdot 0$ & 58.8 & $57 \cdot 8$ & $6 r \cdot 2$ \\
\hline Tyrosine & $33 \cdot 5$ & $6 \cdot 3$ & $30 \cdot 6$ & $9 \cdot 3$ \\
\hline Phenylalanine & $28 \cdot 3$ & $41 \cdot 4$ & $35 \cdot 8$ & 53.5 \\
\hline Lysine & 70.9 & $98 \cdot 0$ & $78 \cdot 4$ & $24: 3$ \\
\hline Histidine & $20 \cdot 0$ & $24 \cdot 8$ & $27 \cdot 2$ & 3.5 \\
\hline Arginine & $34 \cdot 5$ & $39 \cdot 6$ & $38 \cdot 6$ & $21 \cdot 4$ \\
\hline Ammonia & High & $441 \cdot 6$ & $14 I \cdot 4$ & 218.5 \\
\hline
\end{tabular}

in the gamma lysin residues. The $N$-terminal amino acid of gamma lysin is methionine, which is present only in small quantities. Histidine is the $N$-terminus of alpha lysin, while proline is the $N$-terminus of delta lysin. No data are at present available for beta lysin.

\section{Immunological characterization of gamma lysin}

Several immunological experiments distinguish gamma lysin from the other haemolysins. The first of these is quantitative precipitation. Gamma lysin was precipitated by its purified antibody with the formation of a characteristic precipitin curve (Fig. $4 a$ ), while the other haemolysins were precipitated by their respective antisera and did not precipitate with antigamma lysin (Fig. $4 b, c, d$ ). Ouchterlony immunodiffusion tests of the gamma lysin (Fig. $5 a$, $b, c, d$ ) indicate that the lysin formed a single precipitin line with its homologous purified antibody (as did beta, alpha and delta lysins with their antibodies) and that no cross- 

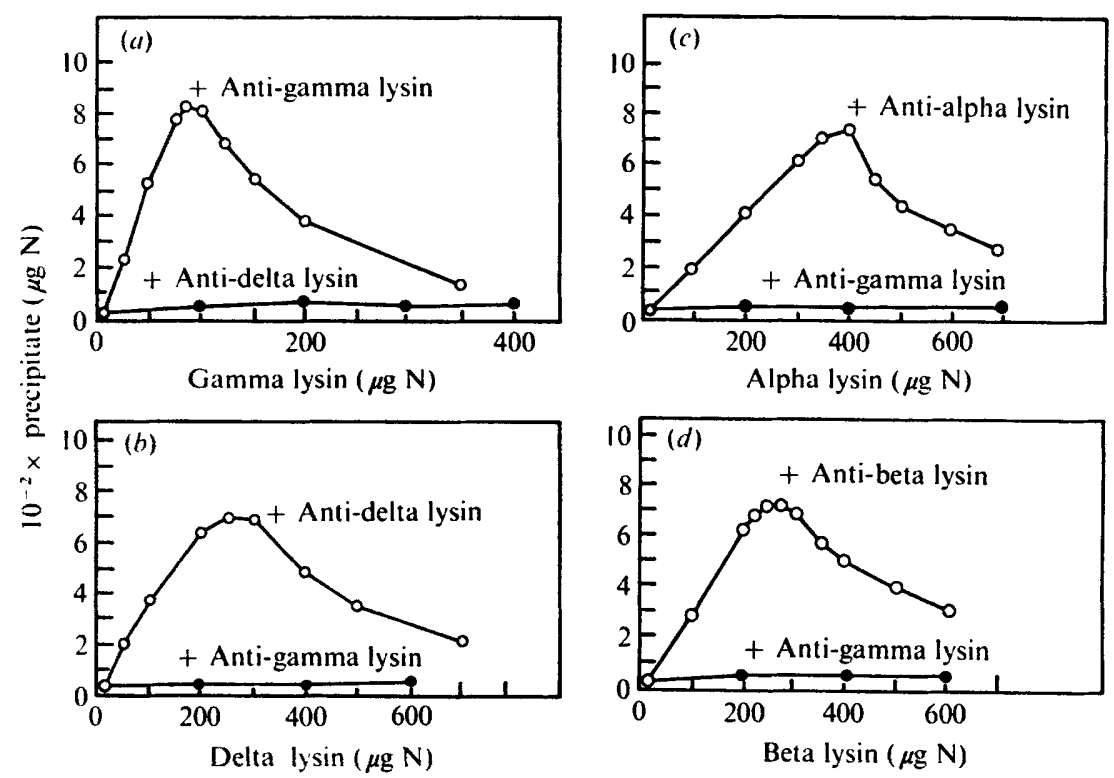

Fig. 4. Quantitative precipitation of purified haemolysins by homologous purified antibody. (a) Precipitation of gamma lysin by antibody to gamma and delta lysins; (b) precipitation of delta lysin by antibody to gamma and delta lysins; (c) precipitation of alpha lysin by antibody to alpha and gamma lysins; $(d)$ precipitation of beta lysin by antibody to beta and gamma lysins.

reactions were observed. These immunodiffusion experiments were repeated in agarose which contained $\mathrm{I} \%$ (v/v) washed erythrocytes. Purified haemolysins were diffused against their respective purified antibodies for $2 \mathrm{~h}$ at $37^{\circ} \mathrm{C}$, after which the plates were cooled to $0{ }^{\circ} \mathrm{C}$ and rapidly dried with blotting paper. Specific antibodies to the haemolysins neutralized the haemolytic activity, and no precipitin line was observed which did not correspond to the edge of the zone of haemolysis (results not shown).

\section{Effect of gamma lysin upon animals}

The toxicity of gamma lysin for mice, rabbits and guinea pigs was investigated. Ten mice per dilution were used, and over the range of o to $100 \mu \mathrm{g}$, gamma, beta and delta lysins had no visible effect on the mice. As expected, the alpha lysin was lethal for mice: the $\mathbf{L D}_{50}$ obtained by probit analysis was $0.68 \pm 0.19 \mu \mathrm{g}$, or 27 to $34 \mu \mathrm{g} / \mathrm{kg}$ mouse tissue. In contrast with the negative results obtained for mice, gamma lysin killed guinea pigs instantly if they were injected intracardially in $50 \mu \mathrm{g}$ amounts. The same result was obtained with alpha lysin, but beta and delta lysins had no effect by this route of injection. Autopsy findings obtained for us by $\mathrm{Dr} \mathrm{H}$. Sayed of this Department were that guinea pigs which received gamma lysin intracardially showed massive haemorrhage of the kidney and serosal surfaces of the intestines and frank lysis of red cells in the major veins and arteries.

Subcutaneous injection of $>\mathrm{I} \mu \mathrm{g}$ alpha lysin caused dermonecrosis in rabbits and guinea pigs, but $100 \mu \mathrm{g}$ quantities of beta, gamma or delta lysins had no effect.

\section{Effect of purified gamma lysin on mammalian cells}

Red cells obtained from eleven species of animals were used in the titration of the four haemolysins (Table 2). Some differences in the haemolytic spectra of the haemolysins were found. Rabbit erythrocytes were most sensitive to the alpha and gamma lysins, in contrast to 

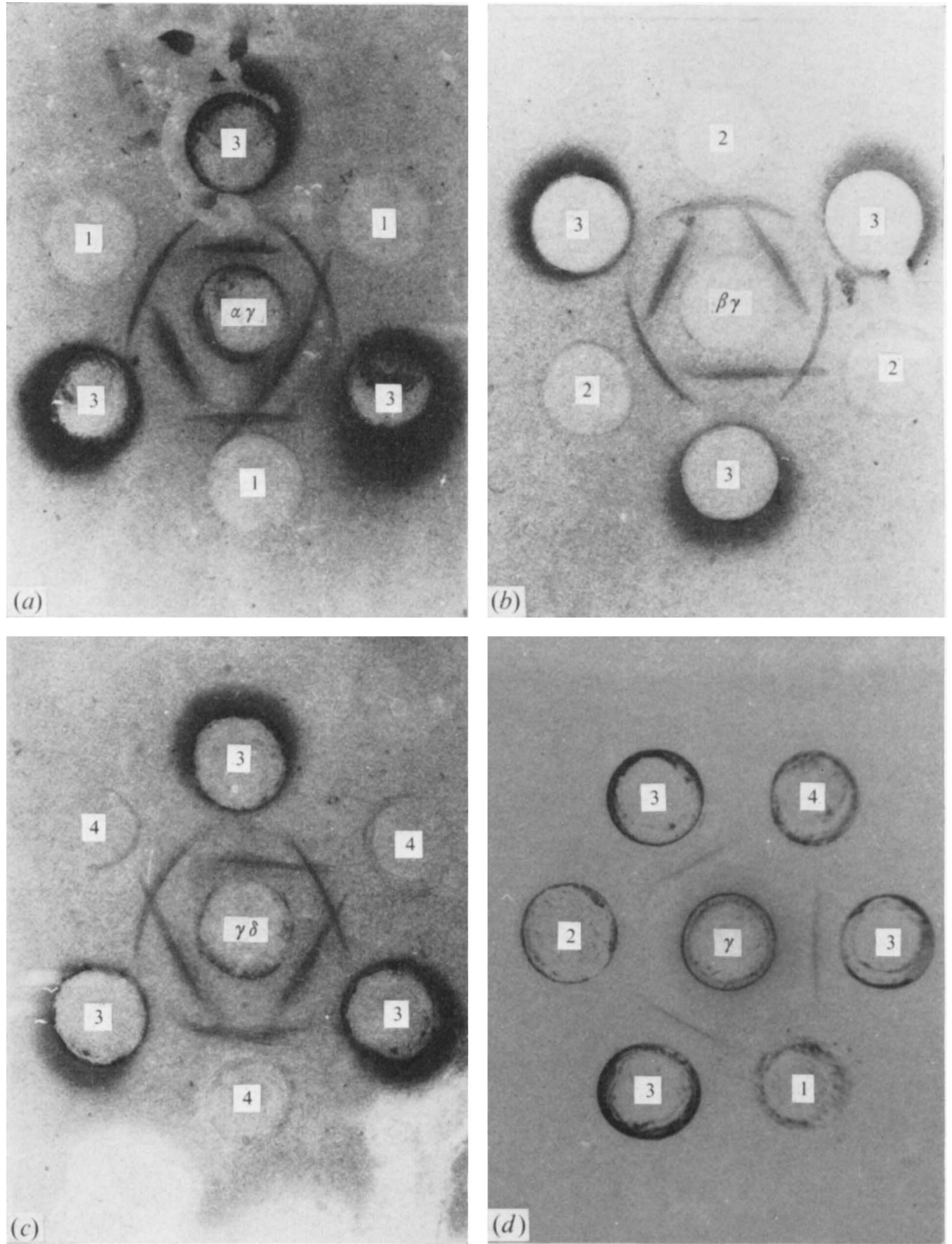

Fig. 5. Ouchterlony double diffusion of purified haemolysins against homologous purified antibodies. The centre wells contain antibody and the peripheral wells the lysins. Well I contains alpha lysin, well 2 beta lysin, well 3 gamma lysin and well 4 contains delta lysin. The centre wells contain: (a) anti-alpha and anti-gamma lysins; (b) anti-beta and anti-gamma lysins; (c) anti-gamma and anti-delta lysins; $(d)$ only anti-gamma lysin. 


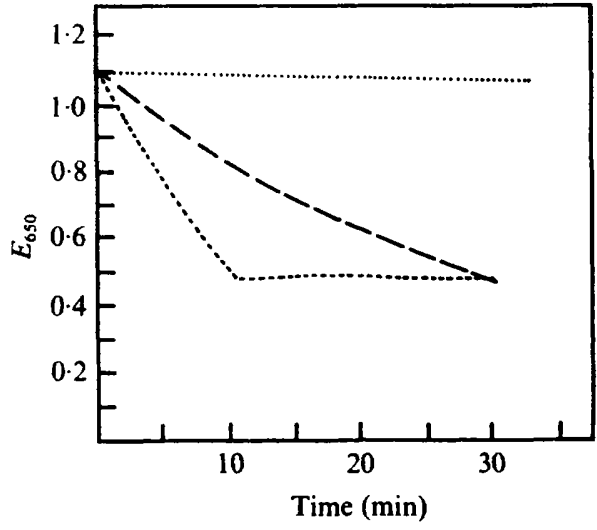

Fig. 6

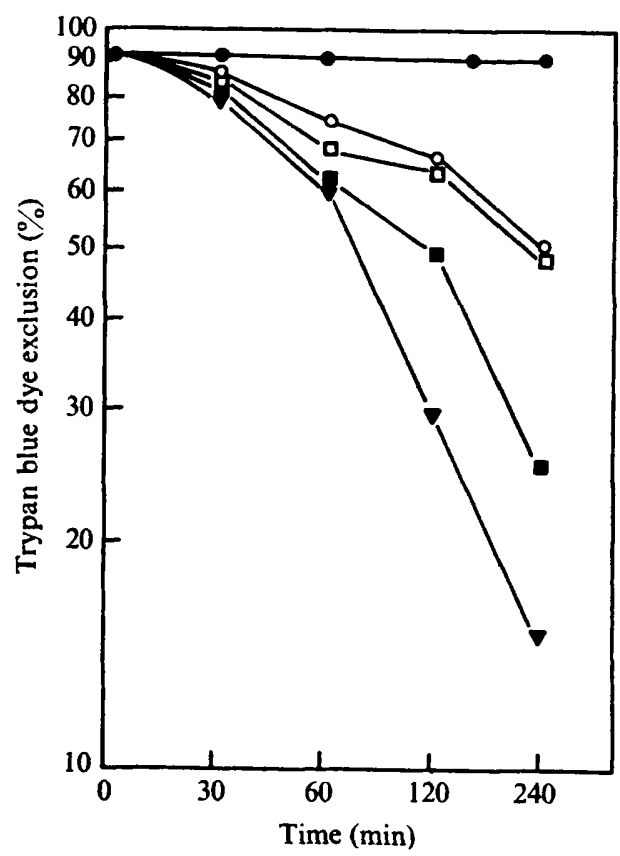

Fig. 7

Fig. 6. Lysis of human leucocytes by gamma and alpha lysins. ....., Leucocytes only; --- , leucocytes + gamma lysin; - - - leucocytes + alpha lysin.

Fig. 7. Effect of gamma lysin on the exclusion of trypan blue by $\mathrm{C}-6$ cells. The concentrations of gamma lysin $(\mu \mathrm{g} / \mathrm{ml})$ were: 0,$0 ; 0,1 \cdot 25 ; \square, 2.5 ; \square, 5 ; \nabla, 10$.

Table 2. Haemolytic activity of staphylococcal lysins

Activity (h.u./mg protein)

\begin{tabular}{lrrrr} 
& Alpha & Beta & Gamma & Delta \\
\cline { 2 - 5 } Rabbit & 76422 & 81300 & 113210 & 1644 \\
Dog & 2906 & $<750$ & 29764 & 882 \\
Rat & 2497 & 4960 & 44041 & 1700 \\
Cat & 2214 & 4760 & 6445 & 1500 \\
Sheep & 1026 & 758830 & 89906 & 2929 \\
Mouse & 1023 & 10000 & 25754 & 1037 \\
Chicken & 83 & 2950 & 306 & 803 \\
Guinea pig & 56 & 63740 & 6620 & 803 \\
Human & 53 & 10360 & 44041 & 7527 \\
Monkey & 26 & $<750$ & 3208 & 749 \\
Pigeon & 5 & 9930 & 160 & 165
\end{tabular}

beta and delta lysins which preferentially lysed sheep and human cells respectively. Monkey and dog cells were most resistant to beta lysin and pigeon cells were refractory to alpha, gamma and delta lysins.

Human leucocytes were incubated at $37^{\circ} \mathrm{C}$ with the gamma lysin. Addition of gamma lysin ( $10 \mu \mathrm{g} / \mathrm{ml}$ ) to the leucocytes caused a relatively linear decrease in extinction of the cells up to Io min (Fig. 6). Beyond that time, no further decrease was observed. Alpha lysin included for comparison showed a nearly linear fall in extinction over a 30 min period. The effect of gamma lysin on C-6 cells was also studied. Various amounts of gamma lysin in $0.5 \mathrm{ml}$ of medium were added to $4.5 \mathrm{ml}$ cell suspension. At different times, $0.5 \mathrm{ml}$ of this 


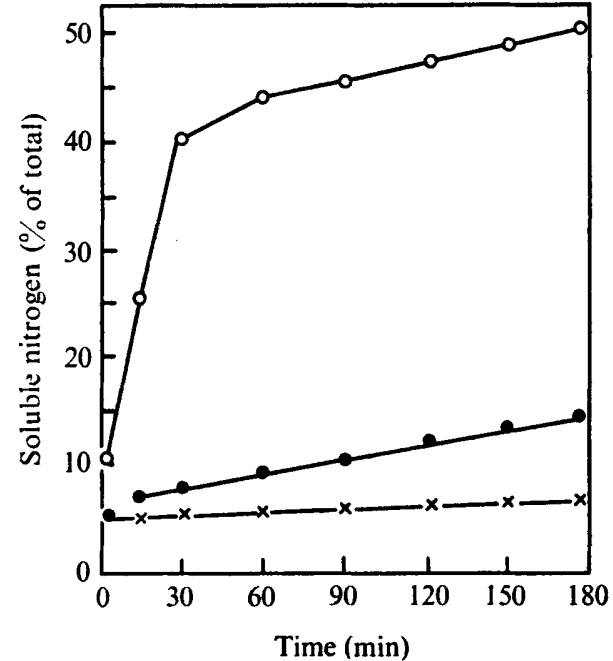

Fig. 8

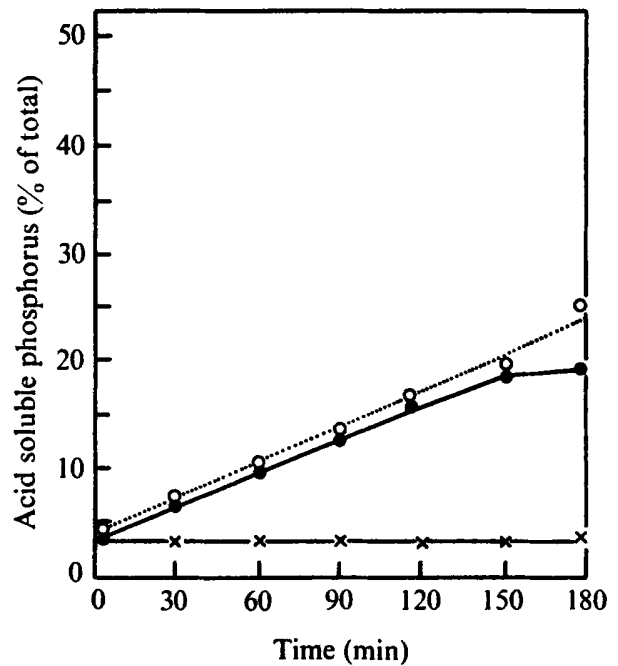

Fig. 9

Fig. 8. Liberation of nitrogen from human erythrocyte membranes in the presence of gamma lysin. Membranes alone $(x)$; membranes treated with gamma lysin $(\bullet)$; membranes treated with pronase (O).

Fig. 9. Liberation of acid-soluble phosphorus from human erythrocyte membranes in the presence of gamma lysin. Membranes alone $(x)$; membranes treated with gamma lysin $(e)$; membranes treated with phospholipase $\mathrm{C}$ (Clostridium perfringens alpha toxin) (O).

suspension was removed and mixed with $0.2 \mathrm{ml}$ of tryphan blue $(0.01 \%$, w/v). At least 700 cells were counted and their ability to exclude the dye was recorded (Fig. 7). About $93 \%$ of the control cells excluded the dye, but after $4 \mathrm{~h}$ incubation with $10 \mu \mathrm{g}$ gamma lysin/ $\mathrm{ml}(700 \mathrm{~h} . \mathrm{u} . / \mathrm{ml})$ only $15 \%$ of the cells excluded the dye and the rate at which cells were affected was proportional to the haemolysin concentration.

\section{Effect of gamma lysin on human erythrocyte membranes}

An attempt was made to show chemical differences in composition of red cell membranes after treatment with gamma lysin. The membranes were added to gamma lysin such that their final concentration in terms of nitrogen was $500 \mu \mathrm{g} / \mathrm{ml}$ while that of the lysin was $50 \mu \mathrm{g} /$ $\mathrm{ml}$ (about 6000 h.u./ml). The suspension was incubated at $37^{\circ} \mathrm{C}$ for $3 \mathrm{~h}$ at which time the reaction was stopped by the addition of trichloroacetic acid to a final concentration of $5 \%$ (w/v). Control (no lysin) and test supernatant fluids showed no difference in total carbohydrate, pentose, deoxypentose, reducing sugars, hexosamines, sialic acid or protein as measured by the Lowry reagent (results not shown). Furthermore, no differences in extinction at 260 or $280 \mathrm{~nm}$ was detected. However, the nitrogen content of the supernatant fluid of the membrane-lysin mixture increased by $7 \%$ in relation to a control without lysin. In addition, acid-soluble phosphorus was released from the membranes by the lysin.

Nitrogen and phosphorus released from membranes were determined at various intervals of time ranging from o to $180 \mathrm{~min}$ in the presence of twice the amount of substrate (Fig. 8). The rate of nitrogen liberation was linear over the $3 \mathrm{~h}$ period. The rate of release was, however, much less than that obtained by treatment of the membranes with pronase. The addition of phospholipase $\mathbf{C}$ to the membranes liberated an amount of phosphorus similar to that given by the lysin (Fig.9). The rate of liberation of phosphorus was greater than that of nitrogen. 


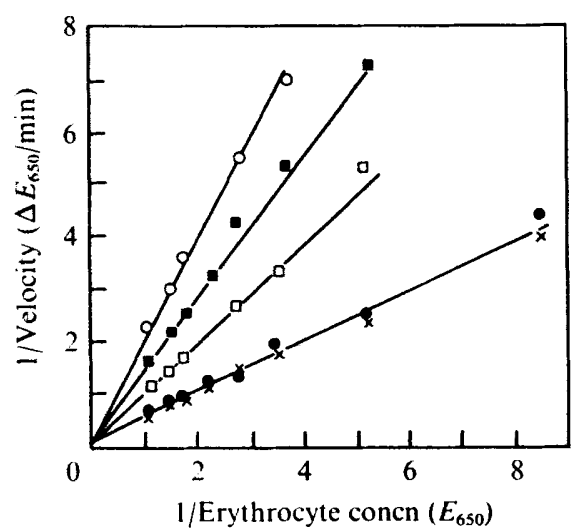

Fig. 10

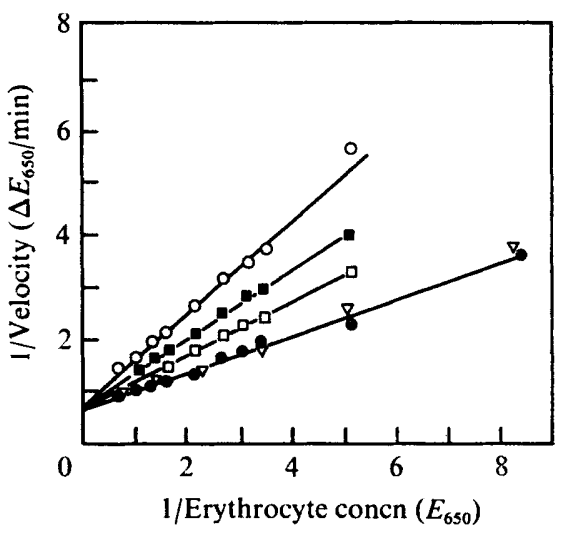

Fig. I I

Fig. 10. Lineweaver-Burk plot of reaction between human erythrocytes and gamma lysin. Gamma lysin-red cell control (O); gamma lysin + red cells to which red cell cytoplasm was added $(x)$; gamma lysin + red cell suspensions at a red cell concentration $(\mu \mathrm{g} \mathrm{N} / \mathrm{ml})$ of: $\square, 20 ; \mathbf{n}, 30 ; 0,40$.

Fig. II. Lineweaver-Burk plot of reaction between human erythrocytes and gamma lysin in the presence of membrane phospholipids. Gamma lysin + human red cells alone ( $\bullet$; gamma lysin + red cells in presence of membrane protein $(\nabla)$; gamma lysin + red cell suspensions to which have been added membrane phospholipids at concentrations $(\mu \mathrm{g} \mathrm{P} / \mathrm{ml})$ of: $\square, 10 ; \boldsymbol{\square}, 20 ; 0,35$.

The phospholipids of human erythrocyte membranes were dialysed at a concentration of I $\mathrm{mg} / \mathrm{ml}$ against tris-saline buffer ( $\mathrm{pH} 7^{\circ}$ ) ) and incubated with $\mathrm{I} 20 \mu \mathrm{g}$ (about $10^{4}$ h.u.) of gamma lysin $/ \mathrm{ml}$. In contrast with results obtained for red cell membranes, no detectable phosphorus was released after $3 \mathrm{~h}$ incubation at $37^{\circ} \mathrm{C}$. None of the phospholipids identified by t.l.c. disappeared from the phospholipid preparation after treatment with gamma lysin. The lysin also did not hydrolyse sphingomyelin and was therefore different from beta lysin (Wiseman \& Caird, 1967). The gamma lysin failed to degrade phosphatidylinositol and was thus unlike delta lysin (Wiseman \& Caird, 1968). Gamma lysin had no effect upon phosphatidylserine, phosphatidylethanolamine or phosphatidylcholine.

A suspension of lipid-free membrane protein $(2 \%, w / v)$ in phosphate buffered saline at $\mathrm{pH} 7.0$ was incubated with gamma lysin $(120 \mu \mathrm{g} / \mathrm{ml})$. No nitrogen was detected in the supernatant liquid after $3 \mathrm{~h}$ incubation at $37^{\circ} \mathrm{C}$, which contrasts with observations made for membranes. No breakdown products were obtained by amino acid and $N$-terminal group detection on t.l.c. plates.

Gamma lysin might act in a manner similar to that reported for the alpha lysin by Wiseman \& Caird (1972) and by Wiseman et al. (1974). Alpha lysin is activated by red cell proteases and is then able to degrade sensitive erythrocytes or other suitable substrates such as $p$-toluene-sulphonyl-L-arginine methylester. However, gamma lysin incubated with red cell membranes (known to activate alpha lysin) failed to hydrolyse this ester.

\section{Kinetics of substrate inhibition of haemolysis}

The velocity of lysis of human red cells incubated with gamma lysin was measured over a range of red cell concentrations and with erythrocyte membranes or red cell cytoplasm ( $\mathrm{I} \mathrm{mg} / \mathrm{ml}$ reaction mixture). The results, expressed in the form of a Lineweaver-Burk plot (Fig. 10), indicate that haemolysis was inhibited by as little as $20 \mu \mathrm{g}$ of erythrocyte membrane nitrogen $/ \mathrm{ml}$. Cytoplasm had no effect on the rate of haemolysis. All curves have a common $y$-intercept. 


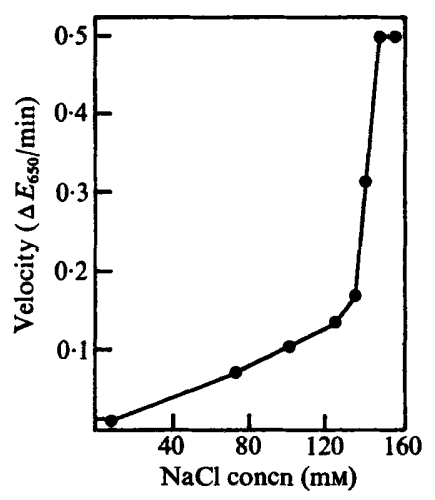

Fig. 12. The effect of $\mathrm{NaCl}$ concentration upon the rate of lysis of human erythrocytes in the presence of gamma lysin. The molarity of the solutions was kept constant $(0.15 \mathrm{M})$ by the addition of appropriate amounts of tris- $\mathbf{H C l}$ buffer or sucrose.

Table 3. Inhibition of gamma haemolysin by EDTA

\begin{tabular}{|c|c|c|}
\hline Treatment & EDTA (M) & $\begin{array}{c}\text { Total } \\
\text { haemolysin } \\
\text { (h.u.) }\end{array}$ \\
\hline Gamma lysin + EDTA solution & $\begin{array}{l}10^{-8} \\
10^{-3} \\
10^{-4} \\
10^{-5} \\
10^{-6} \\
10^{-7}\end{array}$ & $\begin{array}{c}0 \\
0 \\
6500 \\
7300 \\
11200 \\
11800\end{array}$ \\
\hline Gamma lysin + EDTA solution after dialysis & $\begin{array}{l}10^{-2} \\
10^{-8} \\
10^{-4} \\
10^{-5} \\
10^{-6} \\
10^{-7}\end{array}$ & $\begin{array}{l}\text { I I } 900 \\
\text { I } 2100 \\
\text { I I } 600 \\
\text { I I } 750 \\
\text { II } 300 \\
\text { I I } 500\end{array}$ \\
\hline Untreated gamma lysin & 0 & II 800 \\
\hline
\end{tabular}

The experiment was repeated with phospholipid and lipid-free membrane protein components (Fig. II). Human erythrocyte phospholipids at several concentrations competitively inhibited haemolysis by the gamma lysin, whereas lipid-free protein had no effect.

\section{Inhibition of gamma lysin by EDTA}

Haemolysis of human erythrocytes in the presence of gamma lysin was increasingly inhibited at concentrations of EDTA of ${ }^{10} 0^{-6} \mathrm{M}$ or greater (Table 3). Inhibition of haemolysis by EDTA was abolished if the solution!of lysin and chelating agent was dialysed against phosphate buffered saline at $\mathrm{pH} 7 \cdot 0$ for $24 \mathrm{~h}$.

Titration experiments with the following ions showed no enhancement of lysis nor did they restore the activity of lysin-EDTA solutions when tested at concentrations ranging from IO-8 to 0.I M: $\mathrm{Mg}^{2+}, \mathrm{Ca}^{2+}, \mathrm{Fe}^{2+}, \mathrm{Al}^{3+}, \mathrm{Zn}^{2+}, \mathrm{Mn}^{2+}, \mathrm{Ni}^{2+}, \mathrm{Co}^{2+}, \mathrm{NH}_{4}+$ and $\mathrm{Cl}^{-}$. However, a requirement for $\mathrm{Na}^{+}$or $\mathrm{K}^{+}$was demonstrated, and at concentrations of less than $7.5 \times 10^{-3}$ $\mathrm{M}-\mathrm{NaCl}$ no lytic activity was present (Fig. I2). Erythrocytes were washed with tris- $\mathrm{HCl}$ ( $\mathrm{pH} 7.5$ ) containing various concentrations of $\mathrm{NaCl}$ and then incubated with gamma lysin. The total $\mathrm{NcCl}+$ tris $-\mathrm{HCl}$ concentrations were adjusted to $0.15 \mathrm{M}$ to maintain isotonicity. The tris- $\mathrm{HCl}$ could be replaced by sucrose with no adverse effects. 
Table 4. Summary of physico-chemical data for the staphylococcal haemolysis

\begin{tabular}{|c|c|c|c|c|}
\hline & Alpha & Beta & Gamma & Delta \\
\hline Sedimentation constant, $s_{\mathbf{2 0}, \mathbf{w}}$ & $1 \cdot 4,3 \cdot 0^{*}$ & $1 \cdot 8$ & $2 \cdot 6$ & $2 \cdot 8,9 \cdot 8^{*}$ \\
\hline Extinction coefficient, $1 \% 280 \mathrm{~nm}$ & 13.56 & $4 \cdot 24$ & $28 \cdot 35$ & $29 \cdot 08$ \\
\hline Molecular weight by gel filtration & 45000 & 26000 & 45000 & $200000 \dagger$ \\
\hline Isoelectric point & $8 \cdot 5$ & $9 \cdot 5$ & $6 \cdot 0$ & $9 \cdot 6$ \\
\hline$N$-terminal amino acid & Histidine & ND & Methionine & Proline \\
\hline
\end{tabular}

\section{DISCUSSION}

A comparison of the physio-chemical properties of gamma lysin in relation to the alpha, beta and delta lysins is shown in Table 4. Gamma lysin was in several respects similar to alpha lysin. For example, the molecular weights determined on Sephadex G-75 were identical and the two lysins could not be separated by disc electrophoresis (Fig. I). The $E_{280}^{1 \mathrm{~cm}}$ of beta lysin was low compared with other lysins; its pI was similar to that of the delta lysin. The sedimentation coefficient determined in our laboratory for beta lysin was close to the value obtained by Gow \& Robinson (1969). The pI of gamma lysin was $6 \cdot 0$, which is not in agreement with the value (9.5) obtained by Mollby \& Wadstrom (1971). However, the pI of alpha lysin (8.5) agreed well with that given for alpha-I by McNiven, Owen \& Arbuthnott (1972) and for alpha-a published by Wadstrom (I968).

Amino acid analysis of the gamma lysin showed that it contained a large number of aspartic and glutamic acid residues, large amounts of ammonia, and that cysteine was absent or not detected. The alpha, beta and delta lysins also contained high levels of aspartic and glutamic acids and ammonia. These lysins are basic proteins in contrast with the gamma lysin which appears to be acidic, at least on the basis of its pI value of 6.0 . From the amino acid analyses, one would also expect the gamma lysin to be basic, but presumably acidic or basic properties depend upon the presence or absence of some critical number of asparagine or glutamine residues, and the high ammonia content may have been due to the presence of aspartate and glutamate residues as asparagine and glutamine. Unfortunately, amino acid analyses of the beta and gamma lysins have not been published elsewhere and consequently it is not possible to make comparisons. Our amino acid analysis of the delta lysin, however, resembles those of Heatley (1971), Kantor, Temples \& Shaw (1972) and Kreger et al. (1971); arginine, proline, tyrosine and cysteine were absent or present in low concentration while lysine, isoleucine and aspartic acids were present in all preparations in high concentration. Yoshida (1963) also presented an analysis of the delta lysin which is similar to these analyses but his preparation was subsequently shown to be contaminated with other proteins (Gladstone \& Yoshida, 1967). The amino acid analysis of alpha lysin compared reasonably well with those of Coulter (1966), Bernheimer \& Schwartz (1963) and Six \& Harshman (1973). However, the glycine content of our preparation was somewhat higher.

Molecular weight of beta lysin calculated from its behaviour on Sephadex was 26000 daltons, somewhat higher than the value of 15500 obtained by Chesbro \& Kucic (I97I) for the UNH-Donita strain. However, the minimal molecular weight calculated from the amino acid analysis was I6 I 10, and gives better agreement. The molecular weight of beta lysin by Wadstrom \& Mollby (1972) is about twice the value obtained in our laboratory on Sephadex.

The gamma lysin was immunologically distinct from the alpha, beta and delta lysins. It is now abundantly clear from our work and that of others (Guyonnet \& Plommet, 1970; Mollby \& Wadstrom, 197I) that Elek (1959) was incorrect in assuming that gamma and delta lysins were identical. 
Previously it has not been possible to compare the haemolytic spectra of the four haemolysins because one seldom possessed highly purified preparations or had them together at the same time. In the present study this comparison could be made but the data must be interpreted with caution, since red cells are notoriously variable in their sensitivity to a given lysin. Bernheimer (1964) for example has reported that the differences in sensitivity of rabbit and human erythrocytes to alpha lysin may vary I5- to I50-fold.

In toxicity studies, Wadstrom \& Mollby (1972) reported that a dose of less than a milligram of partially purified gamma lysin is lethal for mice and rabbits, unlike our own results. They also found that the $\mathrm{LD}_{50}$ of delta lysin for mice was $125 \mathrm{mg}$, although such a large $\mathbf{L D}_{50}$ is meaningless except to suggest that the lysin is relatively non-toxic for mice. Calculations based on the data of Kreger et al. (197I) give an $\mathrm{LD}_{50}$ of $2 \mathrm{mg}$ of delta lysin for mice and $7 \cdot 2 \mathrm{mg}$ for guinea pigs, but contamination of their preparations with alpha lysin at a concentration of one part in 2000 or less would account for these findings (see Fackrell \& Wiseman, 1974).

Unfortunately, it has not been possible to elucidate the precise mode of action of gamma lysin. However, kinetics of haemolysis and inhibition are not incompatible with a catalytic reaction between gamma lysin and its substrate. Kinetic studies of a reaction in which erythrocytes are used as substrate are not ideal, but we have found such studies useful and at best they may reflect what will be found when the substrate is identified and isolated.

Liberation of nitrogen and phosphorus from membranes treated with gamma lysin suggests that the lysin might be a phospholipase. This view is supported by the fact that membrane phospholipids competitively inhibited lysis but membrane proteins were unable to do so. Against this evidence is the observation that crude extracted or purified phospholipids were not attacked by the gamma lysin. However, the extraction procedure could have altered the substrate so that it was not susceptible to the action of the lysin, since many phospholipids are susceptible to oxidation and other factors. Another possibility is that conformation of the phospholipid substrate changes during extraction which renders it refractory to the action of gamma lysin.

The role of sodium or potassium ions in the interaction of gamma lysin with red cells is unclear. While there are many examples of enzymes which require sodium ions, we cannot reconcile the sodium requirement with the phospholipase-like activity of the gamma lysin.

This study was supported by the University of Manitoba and the Medical Research Council of Canada.

\section{REFEREN CES}

ANDREwS, P. (1964). Estimation of the molecular weights of proteins by Sephadex gel filtration. Biochemical Journal 91, 222-223.

ANSELl, G. B. \& HAWTHORNe, J. N. (1964). Phospholipids - Chemistry, Metabolism and Function. New York: Elsevier.

Balley, J. L. (1967). Techniques in Protein Chemistry, 2nd edn. Amsterdam: Elsevier.

BernHeIMER, A. W. (1964). Staphylococcal alpha toxin. Annals of the New York Academy of Sciences 128, $112-123$.

BernheImer, A. W. \& SchWARTz, L. L. (1963). Isolation and composition of staphylococcal alpha toxin. Journal of General Microbiology 30, 455-468.

CAIRD, J. D., \& Wiseman, G. M. (I970). Purification of the delta toxin of Staphylococcus aureus. Canadian Journal of Microbiology 16, 703-708.

Campbell, D. H., Garvey, S., Cremer, E. \& Sussdorf, H. (1970). Methods in Immunology, 2nd edn. New York: Benjamin.

CHESBRo, W. \& KUCIC, V. (1971). Beta hemolysin: a persistent impurity in preparations of staphylococcal nuclease and enterotoxin. Journal of Applied Microbiology 22, 233-241.

COULTER, J. R. (1966). Production, purification, and composition of staphylococcal alpha toxin. Journal of Bacteriology 92, 1655-1662. 
Dodge, J. T., Mitchell, C. \& Hanahan, D. J. (1963). The preparation and chemical characteristics of hemoglobin-free ghosts of human erythrocytes. Archives of Biochemistry and Biophysics 100, I19-130.

ELEK, S. D. (1959). Staphylococcus pyogenes and its Relation to Disease. Edinburgh: Livingstone.

FACKRELL, H. B. (1974). Studies with Gamma Hemolysin of Staphylococcus aureus. Ph.D. thesis, University of Manitoba.

FACKRELL, H. B. \& WiSEMAN, G. M. (1974). Immunogenicity of the delta hemolysin of Staphylococcus aureus. Journal of Medical Microbiology 7, 4I I-4I4.

Fackrell, H. B. \& Wiseman, G. M. (1976). Production and purification of the gamma haemolysin of Staphylococcus aureus 'Smith 5R'. Journal of General Microbiology 92, I-IO.

Fraenkel-Conrat, H., Harris, J. I. \& Levy, A. L. (1955). Recent developments in techniques for terminal and sequence studies in peptides and proteins. Methods in Biochemical Analysis 2, 359-425.

Gladstone, G. P. \& YoshidA, A. (1967). The cytopathic action of purified staphylococcal delta hemolysin. British Journal of Experimental Pathology 48, $11-19$.

Gow, J. A. \& Robinson, J. (1969). Properties of purified staphylococcal beta hemolysin. Journal of Bacteriology 97, 1026-1032.

Guyonnet, F. \& Plommet, M. (1970). Hemolysine gamma de Staphylococcus aureus: purfication et proprietés. Annales de l'Institut Pasteur 118, 19-33.

Hallander, H. O. (1963). Fractionation of staphylococcal toxins by gel filtration. Acta pathologica et microbiologica scandinavica 59, 543-552.

Heatley, N. G. (1971). A new method for the preparation and some properties of staphylococcal deltahaemolysin. Journal of General Microbiology 69, 269-278.

Ida, S., Saireni, T. \& Hinuma, Y. (1972). Antibodies to a new antigen induced by Epstein-Barr virus in patients with nasopharyngeal carcinoma, leukemia, malignant lymphoma and in control groups. Gann 63, 45-55.

Kabat, E. A. \& MaYer, M. M. (1961). Experimental Immunochemistry, 2nd edn. Springfield: Charles C. Thomas.

Kantor, H. S., Temples, B. \& SHAw, W. V. (I972). Staphylococcal delta hemolysin: purification and characterization. Archives of Biochemistry and Biophysics 151, 142-156.

Kreger, A. S., Kim, K. S., Zaboretsky, F. \& Bernheimer, A. W. (I971). Purification and properties of staphylococcal delta hemolysin. Infection and Immunity 3, 449-465.

Leloir, L. F., \& Cardini, C. E. (1955). In Methods in Enzymology, vol. I, pp. 840-850. New York: Academic Press.

MARINETTI, G. V. (1962). Chromatographic separation, identification and analysis of phosphatides. Journal of Lipid Research 3, 1-20.

MARKHAM, R. (1942). A steam distillation apparatus suitable for micro-Kjeldahl analysis. Biochemical Journal 36, 790-791.

McNiven, A. C., OWen, P. \& Arbuthnott, J. P. (1972). Multiple forms of staphylococcal alpha toxin. Journal of Medical Microbiology 5, I1 3-122.

MollBY, R. \& WADSTROM, T. (197I). Separation of gamma hemolysin from Staphylococcus aureus Smith 5R. Infection and Immunity 3,633-635.

PATAKI, G. (1968). Techniques of thin-layer chromatography in amino acid and peptide chemistry. Ann Arbor: Ann Arbor Science Publishers.

Rose, H. G. \& OKLANDER, M. (1965). Improved procedure for the extraction of lipids from human erythrocytes. Journal of Lipid Research 6, 428-431.

RosenberG, S. A. \& Guidorti, G. (1968). The protein of human erythrocyte membranes. I. Preparation, solubilization and partial characterization. Journal of Biological Chemistry 243, 1985-1992.

Six, H. R. \& Harshman, S. (1973). Purification and properties of two forms of staphylococcal alpha toxin. Biochemistry (American Chemical Society) 12, 2672-2677.

SMITH, M. L. \& PRICE, S. A. (1938). Staphylococcus gamma hemolysin. Journal of Pathology and Bacteriology 47, 379-393.

StahL, E. (1965). Thin Layer Chromatography. New York: Academic Press.

WADSTROM, T. (1968). Studies on extracellular proteins from Staphylococcus aureus. IV. Separation of toxin by isoelectric focusing. Biochimica et biophysica acta 133, 228-242.

Wadstrom, T. \& MOLlBY, R. (1972). Some biological properties of purified staphylococcal hemolysins. Toxicon 10, $511-519$.

Wiseman, G. M. \& CAIRD, J. D. (1967). The nature of staphylococcal beta hemolysin. I. Mode of action. Canadian Journal of Microbiology 13, 369-376.

Wiseman, G. M. \& CAIRD, J. D. (1968). Phospholipase activity of the delta hemolysin of Staphylococcus aureus. Proceedings of the Society for Experimental Biology and Medicine 128, 428-430.

Wiseman, G. M. \& CAIRD, J. D. (1972). Further observations on the mode of action of the alpha toxin of Staphylococcus aureus 'Wood-46'. Canadian Journal of Microbiology 18, 987-992.

Wiseman, G. M., CaIRD, J. D. \& Fackrell, H. B. (1974). Trypsin-mediated activation of the alpha hemolysin of Staphylococcus aureus 'Wood 46'. Journal of Medical Microbiology 8, 29-38.

YoshidA, A. (1963). Staphylococcal delta hemolysin. I. Purification and properties. Biochimica et biophysica acta 71, 655-553. 